\title{
Meeting set fair for squalls
}

\section{Chantilly, Virginia}

ThE United States managed to provide an unseasonably warm February day to herald the first meeting of the United Nations Intergovernmental Negotiating Committee (INC) for a Framework Convention on Climate Change, but inside the conference hall the atmosphere began to turn chilly as soon as the welcoming messages had been delivered. The tenday meeting marks the start of what is supposed to be an eighteen-month period of international negotiations leading to the presentation, at the June 1992 meeting of the UN Conference on Environment and Development in Rio de Janeiro, of a treaty that will commit its signatories to industrial and economic policies aimed at curbing the threat of global warming (see Nature 349, 358; 1991). But the proceedings of the first session of the INC last Monday (4 February) indicated that 18 months could be used up in agreeing on negotiating procedures, without science or economics being mentioned.

After a statement from UN SecretaryGeneral Javier Perez de Cuellar adverting to the "formidable task" ahead of the delegates was read out, the remaining inaugural speakers went through the now familiar issues of scientific uncertainty over the present extent, if any, of anthropogenic global warming, of environmental activism versus economic conservation, and of the need for developed countries to pay, in one way of another, the less developed world not to use oldfashioned polluting technologies as they attempt to build their economic strength. Representing the host country was the chairman of the US President's Council on Environmental Quality, Michael Deland, who at the outset stated the US desiderata of achieving "economic growth with responsible stewardship" of the Earth's resources. His generally cautious speech, which emphasized the importance of recognising "financial and technological realities" in working towards an international treaty, was counterbalanced by more combative remarks from Mustafa Tolba, head of the UN Environment Programme. Tolba declared that there was increasing scientific evidence to suggest that "globals warming may have begun," and that without action a temperature rise of two to five degrees centigrade during the next century was likely.

Tolba also suggested that disagreements between different economic forecasts of the costs of $\mathrm{CO}$, reduction programmes and of the potential costs saved by boosting energy efficiency and maintaining the Earth's climate in its present state were largely due to different assumptions rather than profound disputes over methodology, and that with reasonable cooperation it would be possible for all parties to agree on ways to quantify the costs of global warming and of fighting it.

But in the end it is likely to be fundamental political differences rather than scientific or economic uncertainty that dictates the pace of the INC negotiating process.

David Lindley

\section{Miti aims at small research}

\section{Kyoto}

LAST week saw an unusual little gathering of biologists, physicists, and chemists in Kyoto to discuss atomic-level design of functional structures. The workshop, which formed part of the 10th Science and Technology Forum organized by the Science and Technology Agency (STA) is just one example of blossoming interest in Japan in nanotechnology, a field which with the backing of the powerful Ministry of International Trade and Industry (MITI) seems destined to become Japan's next priority target for industrial research.

In recent years several nanotechnology projects have been launched under STA's imaginative Exploratory Research for Advanced Technology (ERATO) programme which provides teams of young researchers from academia and industry with annual funds of 2-3 million dollars over a period of five years to develop the seeds of new technology.
Now MITI's Agency of Industrial Science and Technology (AIST) is getting in on the act with the launch later this year of a project under the agency's "basic technologies for future industries" (Jiseidai) programme. The project, which Sakaki will participate in, will develop quantum dot and quantum wire devices with a MITI budget of about 5,000 million yen $(\$ 40$ million) over ten years.

Private companies, which typically number 5-8 for Jiseidai projects, will be selected this summer and will include some of Japan's major electronic manufacturers.

MITI sees nanotechnology as opening the way to development of the next generation of gigabit electronic devices early in the next century. But the ministry is also keen to support nanotechnology research because it involves a lot of pure science and a large-scale project might help diffuse Western criticism of Japan's perceived lack of contribution to basic research.
David Swinbanks

\section{Opposition melts away}

Tokyo

JAPAN's nuclear power industry breathed a sigh of relief on 3 February when a pronuclear candidate was elected governor of Aomori Prefecture on the northern tip of the main island of Japan. The local election was seen as a test of public support for ambitious plans by the central government and industry to establish a huge nuclear fuel complex in Aomori for the enrichment of uranium, reprocessing of spent fuel and storage of nuclear waste (see Nature 345, 285; 1990).

The Aomori complex, which is already under construction in Rokkasho village, has become the focus of attention of a growing anti-nuclear power movement in Japan which has recruited support from many of Japan's housewives following the Chernobyl disaster in 1986. A Rokkasho government official who advocated freezing the project was recently elected mayor of the village but then showed little opposition to the complex. And the antinuclear movement was pinning its last hopes on the governor's election.

But the incumbent governor, Masaya Kitamura, who has long supported the project, won by a surprisingly comfortable margin against a candidate who advocated a freeze and another proposing total abandonment. David Swinbanks

RIBOZYME TECHNOLOGY

\section{Cech wins first patent}

New York

More than four years after the first application for ribozyme technology was filed, the US Patent Office has granted the first patent (Number 4,987,071) to Thomas Cech and the University of Colorado.

Ribozymes, RNA catalysts that can specifically cleave other RNA molecules, are likely to have important pharmaceutical and biotechnological applications because of their ability to destroy RNA molecules that code for individual proteins.

Thomas Mann, chairman of United States Biochemical Corporation (USB), which holds an exclusive licence to Cech's work, says the patent covers "a broad range of catalytic RNA molecules, methods of using them and methods of synthesizing [them]". This includes RNA enzymes that cleave RNA at any site except a specific four-nucleotide sequence, CUCU, for which USB already has a commercially available ribozyme product.

The new patent contains 63 separate claims, 10 fewer than when the application was first filed, and has been extensively revised since that time. Other applications are still under consideration, and according to Richard Warburg, a patent lawyer with Fish and Richardson in Boston, a second patent may be awarded to Cech

later this year.
Kevin Davies 